\title{
Brazilian bee pollen: phenolic content, antioxidant properties and antimicrobial activity
}

\author{
Vanilda Aparecida Soares de Arruda, Alexandre Vieria dos Santos, Davi \\ Figueiredo Sampaio, Elias da Silva Araújo, André Luís de Castro Peixoto, \\ Leticia M. Estevinho \& Ligia Bicudo de Almeida-Muradian
}

To cite this article: Vanilda Aparecida Soares de Arruda, Alexandre Vieria dos Santos, Davi Figueiredo Sampaio, Elias da Silva Araújo, André Luís de Castro Peixoto, Leticia M. Estevinho \& Ligia Bicudo de Almeida-Muradian (2021) Brazilian bee pollen: phenolic content, antioxidant properties and antimicrobial activity, Journal of Apicultural Research, 60:5, 775-783, DOI: 10.1080/00218839.2020.1840854

To link to this article: https://doi.org/10.1080/00218839.2020.1840854

曲 Published online: 18 Nov 2020.

Submit your article to this journal $\pi$

Џll Article views: 233

Q View related articles $₫$

View Crossmark data \lceil

4 Citing articles: 3 View citing articles 진 


\title{
ORIGINAL RESEARCH ARTICLE
}

\section{Brazilian bee pollen: phenolic content, antioxidant properties and antimicrobial activity}

\author{
Vanilda Aparecida Soares de Arruda ${ }^{a *}$ (D), Alexandre Vieria dos Santos ${ }^{\mathrm{a}}$ (D), Davi Figueiredo Sampaio ${ }^{\mathrm{a}}$ (D), Elias da \\ Silva Araújo ${ }^{a}$ (D) André Luís de Castro Peixoto ${ }^{b *}$ (D), Leticia M. Estevinho ${ }^{c, d}$ (D) and Ligia Bicudo de Almeida- \\ Muradian ${ }^{\mathrm{a}}$ (D) \\ a Laboratory of Food Analysis, Department of Food and Experimental Nutrition, Pharmaceutical Science School, University of São Paulo, São

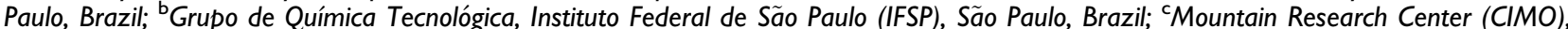 \\ Polytechnic Institute of Bragança, Bragança, Portugal; 'Department of Biology and Biotechnology, Agricultural College of Bragança, \\ Polytechnic Institute of Bragança, Bragança, Portugal
}

(Received 25 May 201 7; accepted 29 April 2020)

\begin{abstract}
Bee pollen has been promoted as a dietary supplement for humans due to its nutritional and bioactive properties. Sixty-two samples of Apis mellifera dehydrated bee pollen collected in Brazil (eight states and Federal District) were analyzed for phenolic compounds, flavonoids, antioxidant activity using DPPH, $\beta$-carotene and ORAC methods, and antimicrobial activity. The values obtained for total phenolic compounds ranged from 12.60 to $84.22 \mathrm{mg}$ GAE/g bee pollen while total flavonoids oscillated between 1.90 and $36.85 \mathrm{mg}$ quercetin/g bee pollen. The $\mathrm{IC}_{50}$ ranged from 0.35 to $13.42 \mathrm{mg}$ bee pollen/mL of extract. The inhibition percentages ranged from 52.58 to $98.37 \%$ of bee pollen extract using the $\beta$-carotene method. When measured by the ORAC method, antioxidant activity was between 132.98 and 575.85 $\mu$ mols eq. Trolox/g bee pollen. Bee pollen efficiently inhibited the growth of all the microorganisms studied. Candida albicans was the most resistant, while Staphylococcus epidermides was the most sensitive.
\end{abstract}

Keywords: antimicrobial activity; bee pollen; dpph; orac; total phenolic compounds; $\boldsymbol{\beta}$-carotene; bleaching assay

\section{Introduction}

Since the dawn of human history, bee pollen has been recognized throughout the world for its nutritional and biological properties and consequent beneficial effects on health. Pollen collected by bees is known to be a balanced foodstuff (Mundargi et al., 2016). Studies have recently been undertaken on the physical and chemical composition, the microbiological quality and the identification of the compounds present in bee pollen and great attention has been dedicated to one particular group, the phenolic compounds (Campos et al., 2015; de Arruda et al., 20I3a, 20I3b; Gabriele et al., 20I5; Mărgăoan et al., 20l4; Yang et al., 20l3).

Researchers worldwide have been dedicating great attention to bee pollen, propolis, and honey, due mainly to the biological properties of these products, such as antibacterial (Basim et al., 2006; Özkalp \& Özcan, 20I0), antifungal (Özcan et al., 2004), anti-inflammatory (Di PaolaNaranjo et al., 2004), anticarcinogenic (Almas et al., 200I; Gebara et al., 2002), antimutagenic (Pascoal et al., 2014) and immunomodulatory activity (Oršolić et al., 2004).

Beehive products are generally considered to be excellent sources of antioxidant substances; studies such (Almaraz-Abarca et al., 2008) which used bee pollen samples from Mexico, and of Campos et al. (2000) which analyzed Portuguese samples of bee pollen have shown a high antioxidant activity of this product. Pollen collected by bees is normally a mixture of pollens of various botanical origins, each one with an important source of flavonoids in the form of glucosides (Wiermann \& Vieth, 1983) and, in some species, of hydroxycinnamic acids. These compounds present species-specific profiles, which suggests that bee pollens collected in different areas or distinct seasons may have different bioactivity (Campos et al., 20I5).

Free radical reactive species are generated in the human organism by various endogenous systems, induced by the exposure to different physiochemical conditions and in pathological states. These may attack bio-molecules, among which lipids, proteins, and DNA are supposed to play a crucial role in a wide range of diseases, like cancer and the cerebrovascular problem (Lobo et al., 20I0).

The daily consumption of antioxidant substances may exercise effective protective action against the antioxidant processes that occur naturally in the organism. A series of diseases - among them cancer, atherosclerosis, diabetes, arthritis, malaria, AIDS, and heart diseases, may be related to the damage caused by highly reactive forms of oxygen, denominated "reactive oxygenated substances" or simply ROS. These substances are also

\footnotetext{
*Corresponding author. Email: cravoecanela.sp@alumni.usp.br
} 
linked to the processes responsible for the aging of the body (Brenna \& Pagliarini, 200I; Yıldırım et al., 200I).

Among several techniques for the determination of antioxidant activity, we chose the three main techniques: DPPH; coupled oxidation of $\beta$-carotene and linoleic acid; and ORAC. With the use of these three distinct techniques (which have different mechanisms), a complete evaluation of the antioxidant activity of bee pollen from different Brazilian regions was proposed, since in the literature, only DPPH, and $\beta$-carotene to evaluate the antioxidant capacity of bee pollen. Besides, it was sought to associate the determination of phenolic compounds and total flavonoids with the results of the antioxidant activity, seeking a possible correlation between them. In this work, samples from several Brazilian regions were evaluated, thus helping to create a database on the composition of bee pollen from various botanical origins and with new data from the application of ORAC (Arruda, 2013).

Considering that regulatory agencies state that any claims of health or nutritional benefits of a food product must be supported by science, the purpose of the present study was to evaluate the content of total phenolic compounds, flavonoids, antioxidant and antimicrobial properties of Brazilian bee pollen (from eight states and Federal District). Furthermore, we emphasize the need for standardization of methods for assessing bee pollen quality and investigating its biological properties, thus adding value to this product.

\section{Materials and methods \\ Samples}

Sixty-two samples of dehydrated bee pollen (from Apis mellifera bees) were collected in the years of 2009-2012, from eight Brazilian states (Bahia, Espirito Santo, Sergipe, Sao Paulo, Santa Catarina, Mato Grosso, Rio Grande do Norte, and the Rio Grande do Sul), and the Federal District. The samples were discussed according to the macro-regions of Brazil: Northeast (Bahia, Sergipe and Rio Grande do Norte states), Mid-west (Federal District), Southeast (Espirito Santo and Sao Paulo states), and South (Santa Catarina and the Rio Grande do Sul states). The samples received were placed in appropriate glass containers and stored at $-18^{\circ} \mathrm{C}$ until analysis. Before the analysis, the samples were homogenized and ground in an analytical mill (Arruda, 20l3).

\section{Preparation of the extracts}

For the preparation of the sample extracts, it was followed by the method reported by Carpes et al. (2007, 2008), with some minor modifications. In an Erlenmeyer flask, $2 \mathrm{~g}$ of dried bee pollen was mixed with $20 \mathrm{~mL}$ of $70 \%$ ethanol, and the solution was heated for $30 \mathrm{~min}$ in the water bath at $70^{\circ} \mathrm{C}$ by mechanical agitation. After cooling at room temperature, the homogenate was filtered through filter paper and transferred to $25 \mathrm{~mL}$ volumetric flasks; the volumes were completed with $70 \%$ ethanol and analyzed for total phenolic compounds, total flavanols, and antioxidant activity. All determinations were performed in triplicate $(n=3)$.

\section{Total phenolic compounds}

The Folin-Ciocalteu method (Carpes et al., 2008) was used to determine total phenolic content. In brief, an aliquot of $0.50 \mathrm{~mL}$ of extract was diluted appropriately in ethanol and then mixed with $2.5 \mathrm{~mL}$ of the FolinCiocalteau reagent: $\mathrm{H}_{2} \mathrm{O}(\mathrm{I}: 10)$. The mixture was, then, incubated at room temperature for five minutes. Finally, $2 \mathrm{~mL}$ of $4 \%$ sodium carbonate $\left(\mathrm{Na}_{2} \mathrm{CO}_{3}\right)$ was added. After incubation at room temperature, for two hours, in the dark, the absorbance of the reaction mixture was measured at $740 \mathrm{~nm}$ against an ethanol blank using a Shimadzu UV I650PC spectrophotometer. The total phenolic content was expressed on a dry basis in $\mathrm{mg}$ of gallic acid equivalents (GAE)/g of bee pollen.

\section{Total flavanols}

The determination of total flavanol content was performed colorimetrically using quercetin as a standard (Carpes et al., 2008). Briefly, the extract was diluted appropriately in ethanol. An aliquot of $0.50 \mathrm{~mL}$ of extract solution was mixed with $4.3 \mathrm{~mL}$ of $80 \%$ ethanol, $0.1 \mathrm{~mL}$ of aluminum nitrate at $10 \%$, and $0.1 \mathrm{~mL}$ of $\mathrm{I} \mathrm{mol} / \mathrm{L}$ of potassium acetate. Similarly, a blank was prepared without aluminum nitrate. The sample and blank absorbances were measured at $415 \mathrm{~nm}$ after $40 \mathrm{~min}$ in the dark at room temperature (Shimadzu - UV I650 PC spectrophotometer). The total flavonol content was expressed on a dry basis in $\mathrm{mg}$ of quercetin equivalent/g of bee pollen.

\section{Antioxidant activity}

Antioxidant properties of bee pollen extracts were evaluated according to ORAC, DPPH, and beta-carotene bleaching (BCB) assays. Indeed, according to Sakanaka and Ishihara (2008) due to the complex nature of bee pollen, it is recommended to access antioxidant activity using more than one methodology in order to avoid possible interferences.

\section{Scavenging of DPPH radicals}

The free radical-scavenger activity was determined by the DPPH assay, as described by Carpes et al. (2008), with some modifications. By a dilution series, the antiradical activity of the extracts was evaluated in order to obtain a large spectrum of sample concentrations. This involved the mixing of $1.5 \mathrm{~mL}$ of DPPH solution $\left(6.0 \times 10^{-5} \mathrm{M}\right.$ in ethanol) with $0.5 \mathrm{~mL}$ of extract solution and $2 \mathrm{~mL}$ of ethanol, followed by homogenization. After $30 \mathrm{~min}$, the quantification of the remaining DPPH radicals was recorded by using absorption set at $517 \mathrm{~nm}$ (Shimadzu UV I650PC 
spectrophotometer). A test tube containing $2.5 \mathrm{~mL}$ of ethanol and $1.5 \mathrm{~mL}$ of DPPH $\left(6.0 \times 10^{-5} \mathrm{M}\right)$ was used as a negative control. The specific sample blank was determined using $3.5 \mathrm{~mL}$ of ethanol and $0.5 \mathrm{~mL}$ of the extract solution of each concentration. Results are presented in $I_{50}$ values, which represent the weight of the sample required to scavenge $50 \%$ of the DPPH radicals available. The extract concentration providing $50 \%$ of radical scavenging activity $\left(\mathrm{IC}_{50}\right)$ was calculated by interpolation from the graph of RSA percentage against extract concentration. The standards used were $\alpha$-tocopherol $\left(\mathrm{IC}_{50}=16.55 \mu \mathrm{g} /\right.$ $\mathrm{mL}), \mathrm{BHT}\left(\mathrm{IC}_{50}=17.06 \mu \mathrm{g} / \mathrm{mL}\right)$ and $\mathrm{BHA}\left(\mathrm{IC}_{50}=8.47 \mu \mathrm{g} /\right.$ $\mathrm{mL}$ ) tested at a concentration of $40 \mathrm{mg} / \mathrm{mL}$.

\section{$\beta$-Carotene bleaching (BCB) assay}

The assessment of the antioxidant activity of the extracts of dehydrated bee pollen was carried out following the method described by Ahn et al., (2004) and Carpes et al. (2008). A solution was prepared by dissolving $20 \mathrm{mg}$ of $\beta$-carotene in I $\mathrm{mL}$ of chloroform, and $30 \mu \mathrm{mL}$ was added to $40 \mathrm{mg}$ of linoleic acid and $400 \mathrm{mg}$ of Tween 40 emulsifier. Then the organic solvent was removed under a stream of nitrogen gas, and $100 \mathrm{~mL}$ of distilled water was added to the Erlenmeyer. The mixture was shaken, and $3 \mathrm{~mL}$ of this emulsion was transferred into different test tubes containing $300 \mu \mathrm{L}$ of extract diluted in $70 \%$ ethanol $(1: 20)$. The tubes were shaken and incubated at $50^{\circ} \mathrm{C}$. As soon as the emulsion was added to all tubes, zero-time absorbance was measured at $470 \mathrm{~nm}$. Oxidation of the emulsion was monitored at 15-min intervals over a 120-min period. Control sample contained $300 \mu \mathrm{L}$ of $70 \%$ ethanol in place of the extract. The antioxidant activity was expressed as percent inhibition relative to the control after a 120-min incubation using the eq. (I)

$$
A A=\frac{\left(D R_{C}-D R_{S}\right)}{D R_{C}} \times 100
$$

where $A A$ is the antioxidant activity, $D R C$ is the degradation rate of the control $(=\ln (a / b) / / 20), D R_{S}$ is the degradation rate in the presence of the sample $(=\ln (a / b) /$ 120), $a$ is the initial absorbance at time 0 , and $b$ is the absorbance at $120 \mathrm{~min}$. The reference standards used were $\alpha$-tocopherol (97.30\%), BHT (95.75\%), and BHA $(97.89 \%)$ tested at a concentration of $40 \mathrm{mg} / \mathrm{mL}$.

\section{Antioxidant activity (ORAC) assay}

ORAC procedure used an automated plate reader (Synergi HT, Bio TeK, USA) with 96-well plates (Arruda et al., 20I3; Ou et al., 200I). Analyses were conducted in a $\mathrm{pH} 7.4(75 \mathrm{mM})$ phosphate buffer at $37^{\circ} \mathrm{C}$ under the condition with a blank sample in parallel. The extracts were diluted with sodium phosphate buffer $(75 \mathrm{mM}, \mathrm{pH}$ 7.4). The peroxyl radical was generated using 2,2'-azobis (2-amino-propane) dihydrochoride aqueous solution - that was prepared for each run
(I53 mM). Fluorescein was used as a substrate $(40 \mathrm{nM})$. The ORAC analyzer was programmed to record the fluorescence of FL every minute after the addition of AAPH. All fluorescent measurements were expressed relative to the initial reading. Fluorescence analysis conditions were performed as follows: excitation at $493 \mathrm{~nm}$ (filter 485/20) and $515 \mathrm{~nm}$ (filter 528/20). The standard curve was linear from 6.25 to $100 \mu \mathrm{M}$ Trolox ${ }^{\circledR}$. Results were calculated using the differences of areas under the FL decay curves between the blank and a sample and were expressed as $\mu \mathrm{mol}$ eq. Trolox/g bee pollen.

\section{Antimicrobial activity}

The microorganisms Escherichia coli ESA37, Staphylococcus epidermides ESA7, and Candida albicansESAI09 were isolated at the Local Health Units of Bragança and identified at the Laboratory of Microbiology of the School of Agriculture of Bragança (Portugal). The isolates were stored in Muller-Hinton medium plus $20 \%$ glycerol at $70^{\circ} \mathrm{C}$. Before experimental use, cultures from the solid medium were subcultivated in liquid media, incubated at $37^{\circ} \mathrm{C}$ over night and used as the source of inocula for each experiment. The inocula for the tests were prepared by diluting cell mass in $0.85 \% \mathrm{NaCl}$ solution, adjusted to 0.5 on the MacFarland scale, confirmed by spectrophotometrical reading at $580 \mathrm{~nm}$ for bacteria and $640 \mathrm{~nm}$ for yeasts. Cell suspensions were finally diluted to $10^{8}$ for bacteria and $10^{5}$ $\mathrm{CFU} / \mathrm{mL}$ for yeasts, so they could be used in the activity assays.

Screening of antibacterial activities was performed by measuring the minimal inhibitory concentrations (MICs in $\mathrm{mg}$ of extract $/ \mathrm{mL}$ ) which were determined by using Nutrient Broth (NB) or Yeasts Peptone Dextrose (YPD) on a microplate (96 wells), per Duarte et al. (2007), and Morais et al. (20II). Pollen extracts were diluted in $20 \%$ DMSO and transferred into the first well, and serial dilutions were performed. Fluconazole (antimycotic) and gentamicin (antibacterial) were used as controls. In each experiment, a positive control (inoculated medium) and negative control (medium), extracts blanks (mediums with compounds), and DMSO control (DMSO with inoculated medium) was introduced. The inoculum $(20 \mu \mathrm{L})$ was added to all the wells and the plates were incubated at $37^{\circ} \mathrm{C}$ for $24 \mathrm{~h}$ (bacteria) and $25^{\circ} \mathrm{C}$ for $48 \mathrm{~h}$ (yeasts). Antimicrobial activity was observed by addition of $20 \mu \mathrm{L}$ of $0.5 \%$ TTC solution. The lowest concentration of bee pollen extract that inhibited visible growth was defined as the minimal inhibitory concentration (MIC), as indicated by the TTC staining.

\section{Statistical analysis}

Comparisons between regions were performed by One-Dimensional Analysis of Variance (One-way ANOVA) followed by the Tukey test. 
Table I. Results of the variation of phenolics, flavonoids and antioxidant activity of the ethanol extracts of the samples of dehydrated bee pollen: $I_{50}(\mathrm{mg}$ pollen $/ \mathrm{mL}$ extract), $\beta$-carotene system (\%), ORAC ( $\mu \mathrm{mol}$ eq.Trolox/g pollen), grouped by region of collection by ANOVA.

\begin{tabular}{|c|c|c|c|c|c|}
\hline Variable & Region & Average & SD & $\mathrm{N}$ & $\mathrm{p}^{*}$ \\
\hline Total phenolic compounds (mg GAE/g pollen) & $\begin{array}{l}\text { Northeast } \\
\text { Mid-west } \\
\text { Southeast } \\
\text { South } \\
\text { Total }\end{array}$ & $\begin{array}{l}19.28 \\
23.86 \\
30.66 \\
36.94 \\
27.94\end{array}$ & $\begin{array}{r}4.42 \\
12.52 \\
15.54 \\
15.70 \\
14.30\end{array}$ & $\begin{array}{r}19 \\
5 \\
25 \\
13 \\
62\end{array}$ & 0.002 \\
\hline Total Flavonoids (mg quercetin/g pollen) & $\begin{array}{l}\text { Northeast } \\
\text { Mid-west } \\
\text { Southeast } \\
\text { South } \\
\text { Total }\end{array}$ & $\begin{array}{l}5.06 \\
4.60 \\
4.81 \\
9.95 \\
5.95\end{array}$ & $\begin{array}{r}2.77 \\
0.61 \\
2.66 \\
10.10 \\
5.43\end{array}$ & $\begin{array}{r}19 \\
5 \\
25 \\
13 \\
62\end{array}$ & 0.025 \\
\hline DPPH IC 50 (mg pollen/mL extract) & $\begin{array}{l}\text { Northeast } \\
\text { Mid-west } \\
\text { Southeast } \\
\text { South } \\
\text { Total }\end{array}$ & $\begin{array}{l}4.18 \\
7.77 \\
2.74 \\
1.68 \\
3.37\end{array}$ & $\begin{array}{l}1.63 \\
5.47 \\
2.27 \\
0.62 \\
2.72\end{array}$ & $\begin{array}{r}19 \\
5 \\
25 \\
13 \\
62\end{array}$ & $<0.001$ \\
\hline$\beta$-carotene/ linoleic acid system (\%) & $\begin{array}{l}\text { Northeast } \\
\text { Mid-west } \\
\text { Southeast } \\
\text { South } \\
\text { Total }\end{array}$ & $\begin{array}{l}76.84 \\
72.38 \\
83.39 \\
90.27 \\
81.94\end{array}$ & $\begin{array}{r}10.76 \\
13.96 \\
10.71 \\
5.10 \\
11.34\end{array}$ & $\begin{array}{r}19 \\
5 \\
25 \\
13 \\
62\end{array}$ & 0.001 \\
\hline
\end{tabular}

*Descriptive level of the statistical test.

The existence of associations between the variables was analyzed using the Pearson correlation test and adopting the Pearson's correlation $(r)$ as the parameter to evaluate the nature (directly or inversely proportional) and the intensity of these correlations ( 0 to I, with I indicating maximum correlation).

The Spearman correlation was adopted for the correlation test; for the comparison of two groups, the Mann-Whitney test was employed, and for more than two groups, the Kruskal-Wallis test was used.

The results were expressed as means of the results \pm standard deviation. All statistical analyses were performed using the program STATISTICA 8.0 and adopted the significance level of $5 \%(p<0.05)$.

\section{Results}

\section{Total PhenolicContent andTotal flavanols}

The results obtained for the total phenolics varied between 12.60 and $84.22 \mathrm{mg} \mathrm{GAE} / \mathrm{g}$ of bee pollen and total flavanols ranged between 1.90 and $36.85 \mathrm{mg}$ of quercetin/g of bee pollen (Table I).

\section{Antioxidant activity}

DPPH radical-scavenging activity

A series of dilutions was undertaken, using the DPPH method, to determine the antioxidant activity of the samples to obtain data for different concentrations (20 to $0.025 \mathrm{mg}$ of pollen/mL of solution). The $I_{50}$ was determined in the interval which presented linearity, and the antioxidant activity was inversely proportional to the $\mathrm{IC}_{50}$.

$\beta$-Carotene bleaching (BCB) assay

When using the $\beta$-carotene method, the antioxidant activity of the samples was between 52.58 and $98.37 \%$ (Table I).

\section{Oxygen radical absorbance capacity (ORAC)assay}

When quantified by the ORAC method, the antioxidant activity varied from $132.98 \pm 1.58$ to $575.85 \pm$ I I. $67 \mu \mathrm{mol}$ eq. Trolox/g pollen (Table I).

\section{Antimicrobial activity}

The results obtained for the antimicrobial activity are presented in Table 2. It may be seen that all the extracts under study possessed antimicrobial activity, with different MIC values for each microorganism. The results were consistent with observed by (Fatrcová-Šramková et al., 20/3). C. albicans showed the most significant resistance, $S$. epidermides being the most sensitive (Table 2). Grampositive bacteria (S. epidermides) presented MICs oscillating between 0.98 and $2.87 \%(w / v)$. For $E$. coli, the values ranged from 1.8 to $7.48 \%(\mathrm{w} / \mathrm{v})$, while for $C$. albicans, the values were between 10.23 and $18.83 \%(w / v)$. There was no average statistically significant difference in the 
Table 2. Results of the variation of antimicrobial activity of the ethanol extracts of the samples of dehydrated bee pollen and comparison of the regions of collection by ANOVA. (MIC in $\mathrm{mg}$ of extract $/ \mathrm{mL}$ ).

\begin{tabular}{llccrc}
\hline Variable & Region & Average & SD & N & $\mathrm{P}^{*}$ \\
\hline E. coli & Northeast & 4.92 & 1.75 & 19 & 0.934 \\
& Mid-west & 5.13 & 1.31 & 5 & \\
& Southeast & 4.78 & 1.27 & 25 & \\
& South & 5.05 & 1.34 & 13 & \\
& Total & 4.91 & 1.42 & 62 & \\
S. epidermides & Northeast & 1.71 & 0.60 & 19 & 0.809 \\
& Mid-west & 1.91 & 0.67 & 5 & \\
& Southeast & 1.79 & 0.59 & 25 & \\
& South & 1.91 & 0.58 & 13 & \\
& Total & 1.80 & 0.59 & 62 & \\
& Northicans & 13.22 & 3.14 & 19 & $>0.999$ \\
& Mid-west & 13.26 & 2.58 & 5 & \\
& Southeast & 13.20 & 2.66 & 25 & \\
& South & 13.27 & 3.42 & 13 & \\
& Total & 13.23 & 2.90 & 62 & \\
\hline
\end{tabular}

*Descriptive level of the statistical test.

antimicrobial parameters as between the Brazilian regions $(p>0.05)$.

\section{Discussion}

\section{Total phenolic content and total flavanols}

Neves et al. (2009) on assessing samples of dehydrated bee pollen from the states of Alagoas, Bahia, Sergipe, and Minas Gerais (Brazil) found values between 6.9 and $13.78 \mathrm{mg} \mathrm{GAE} / \mathrm{g}$ of bee pollen and 3.46 and $6.87 \mathrm{mg}$ of quercetin/g for total phenolics and total flavonols, respectively. Carpes et al. $(2007,2008)$ when analyzing dehydrated samples of bee pollen from the South of Brazil found results which varied between 19.28 and $48.90 \mathrm{mg} \mathrm{GAE} / \mathrm{g}$ for total phenolics and values between 2.10 and $28.33 \mathrm{mg}$ of quercetin/g of pollen for total flavonols, whereas for samples from Paraná and Alagoas (Brazil), respectively, were reported values of 10.90 and $8.10 \mathrm{mg} \mathrm{GAE} / \mathrm{g}$ for total phenolics. Liberato et al. (2009), when assessing samples produced in the state of Ceará (Brazil), reported values of from 17.79 to $19.52 \mathrm{mg} \mathrm{GAE} / \mathrm{g}$ of bee pollen for total phenolics and values between 6.90 and $8.26 \mathrm{mg}$ of quercetin/g of pollen for total flavonols. Vecchia and Carpes (2010) analyzed samples originating in the state of Paraná (Brazil), and found values between 5.36 and $42.79 \mathrm{mg} \mathrm{GAE} / \mathrm{g}$ of dehydrated bee pollen for total phenolics and values between 0.63 and $28.74 \mathrm{mg}$ of quercetin/g of bee pollen for total flavonols, while Meneses et al. (2010) reported values of from I4.3I to $64.14 \mathrm{GAE} / \mathrm{g}$ of dehydrated bee pollen for total phenolics in samples produced in the region of Alagoinhas, in the state of Bahia (Brazil).

The composition of bee pollen varies significantly as a result of collection from different geographic regions, the time of collection, and various species of vegetation from which the pollen is harvested by honey bee (Arruda et al., 2013; Campos et al., 2015). The robust antioxidative properties of polyphenols result from both the double bonds and the location of hydroxyl groups on the aromatic ring. Moreover, polyphenols ring structure determines their lipophilic properties, especially in the case of flavonoids. Hydrophobic antioxidants play a protective role in lipid membranes. Polyphenols can scavenge reactive oxygen species and make organic radicals ineffective and can complex metal ions which catalyze oxidation reactions. Bee pollen shows a robust antioxidative activity owing to various compounds contained in it. Additionally, bee pollen is a source of hydrophilic antioxidants which protect against oxidative structure damage to the cytoplasm, inside cell organelles, and in the extracellular fluid.

\section{DPPH}

The concentration of $10 \mathrm{mg}$ of bee pollen/mL of solution was observed to demonstrate the highest antioxidant activity for most of the samples. Some samples presented the maximum antioxidant activity in concentrations inferior to $10 \mathrm{mg}$ of pollen/mL of solution, and consequently, a low $\mathrm{IC}_{50}$, suggesting the high antioxidant activity of the compounds present in the ethanol extract. Carpes et al. (2008) used a concentration of $2.7 \mathrm{mg}$ of bee pollen/mL of the solution to determine the antioxidant activity of the extracts; while Vecchia and Carpes (2010) tested extracts at a concentration of $6.6 \mathrm{mg}$ bee pollen $/ \mathrm{mL}$ of solution. The antioxidant activity obtained by those researchers was identical to that determined by the present study when one used the concentration of $10 \mathrm{mg}$ of pollen/mL of solution. Synthetic antioxidants used as controls presented higher antioxidant activity than that of the samples analyzed. To make more evident the comparison of the results with those obtained in the literature, DPPH was expressed as $I_{50}$.

The products of the hive are taken as excellent sources of antioxidants according to the studies of Arruda et al. (20I3), Campos et al. (20I5), Morais et al. (20II), and Pascoal et al. (20l4). The results found for the antioxidant activity of Brazilian bee pollen vary considerably among the samples, the value of $\mathrm{IC}_{50}$ oscillated from 0.35 to $13.42 \mathrm{mg}$ pollen $/ \mathrm{mL}$ of extract. Carpes et al. (2008) that analyzed the antioxidant activity of the ethanolic extracts of bee pollen from the southern region of Brazil, obtained $\mathrm{IC}_{50}$ values from $0.8 \mathrm{I}$ to $4.69 \mathrm{mg}$ pollen/ $\mathrm{mL}$ of extract. Campos et al. (2003), using bee pollen samples from Portugal and New Zealand, found $\mathrm{IC}_{50}$ values of between 0.04 and $0.5 \mathrm{mg}$ of bee pollen $/ \mathrm{mL}$ of extract.

\section{$\beta$-Carotene bleaching (BCB) assay}

This method determines the ability of an antioxidant to protect a lipid substrate (in this case, $\beta$-carotene) using the inhibition of free radicals generated during the peroxidation of linoleic acid. These variations may be caused by the differences in their potential and/or in 
the concentration of the various reducing substances, mainly the ample class of the phenolic compounds. In the study undertaken by Carpes et al. (2008), who assessed the antioxidant activity of samples of bee pollen from the South of Brazil, using the same method of analysis, observed that the antioxidant activities of the extracts of bee pollen ranged from 69.78 to $93.12 \%$ (an average of $83.60 \%$ ).

\section{ORAC}

This method is highly sensitive and tests the scavenging ability of an antioxidant about the formation of a radical-induced from 2,2'-azobis (2-amidinopropane) dihydrochloride $(\mathrm{AAPH})$ at $37^{\circ} \mathrm{C}$. The radical reacts with a fluorescent compound forming a non-fluorescent product. The protective effect of the antioxidant is verified by calculating the area created under the curve of the diminution of the fluorescence of the sample against time, as compared with the control, which does not present antioxidant activity.

The Brunswick Laboratory (16th October 2002) obtained results identical to those ascertained in the present study, even though it is not specified whether bee pollen was dehydrated. Indeed, that laboratory compared data obtained using the ORAC assay of High

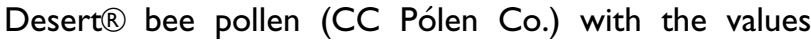
obtained on whole-grain food. A value of $247 \mu \mathrm{mol}$ eq. Trolox/g of pollen was attributed to High Desert bee pollen.

It was found significant differences $(p<0.05)$ amongst the average values of the antioxidant parameters of the different samples of Brazilian dehydrated bee pollen.

The use of distinct concentrations of the bee pollen extracts in the three methods of evaluation of the antioxidant activity hampers the direct comparison of the results obtained following the different methodologies. This observation was also made by Carpes et al. (2008), who undertake studies with dehydrated bee pollen collected in Brazil (southern region). Each sample presented a different result when evaluated by each of the three methods used for the quantification of their antioxidant activity. These different results can be explained by differences in the methodology reaction mechanisms and depend on the specific free radical being used as a reactant.

\section{Antimicrobial activity}

Natural products have been used in traditional medicine throughout the world for thousands of years (Ozan et al., 2007). Indeed, natural substances have demonstrated antibacterial action, mainly because a large part of the vegetable extracts used in alternative medicine consists of flavonoids, cafeic, benzoic and cinnamic acids which act on the bacterial cells in such a way as to break the cytoplasmatic membrane or destroy the cell wall of the microorganism, causing it both functional and structural damage. Also, they can inhibit the activity of many enzymes (Nogueira et al., 2007; Scazzocchio et al., 2006; Uzel et al., 2005).

Morais et al. (20II) observed that Portuguese bee pollen inhibited the growth of bacteria in similar, meager, concentrations. Knazovická et al. (2009) and Kacaniová et al. (2012) attributed the variation in the antimicrobial activity of bee pollen and propolis to their constituent phenolics and the presence of non-volatile compounds in the extracts. Pereira et al. (2007) and Estevinho et al. (2008) demonstrated that the antimicrobial activity of nuts and honey was related to the amount of total phenolic compounds. This fact was not observed in the study carried out by Morais et al. (20II) in which bee pollen extract, with a smaller total phenolic compound, was the most effective against microorganisms. Other factors may be involved; specifically, the nature of the phenolic fraction tested in the study.

In the present study, similarly to Morais et al. (20I I), Graikou et al. (20ll), Abouda et al. (20l I), and Fatrcová-Šramková et al. (2013), Gram-positive bacteria were more sensitive to the extracts of bee pollen than Gram-negative. The reason for this less intense action of the extracts of bee products against Gram-negative than against Gram-positive bacteria is still not well understood; some hypotheses suggest that the resistance of the former microorganisms is related to their possessing a chemically more complex, though flexible, cell wall and because they present a higher lipid content than that observed in Gram-positive bacteria (Morais et al., 20II; Özkalp \& Özcan, 2010).

Carpes et al. (2007) undertook a study to determine the antioxidant activity, phenolic compounds, and antibacterial activity of extracts of bee pollen obtained with different concentrations of ethanol (40 to $90 \%$ ) for samples of dehydrated bee pollen collected in the states of Alagoas and Paraná (Brazil) and observed that the ethanolic extract of bee pollen inhibited S. aureus at $90 \%$. The $60 \%$ extract of the ethanol solution (sample from Paraná) inhibited the microorganisms Bacillus subtilis, Pseudomonas aeruginosa, and Klebsiella spp. (Gondim, $20 \mathrm{II})$ ascertained the antimicrobial effect of bee pollen at a concentration of $5 \%$ (in $70 \%$ ethanol) on Streptococcus mutans, Streptococcus salivarius, Streptococcus mitis, and Lactobacillus casei, observing that bee pollen was efficient against all these bacteria.

Differently from the results hereby reported and to the described studies mentioned above, Carpes et al. (2009) who assessed thirty-six samples of dehydrated bee pollen from the southern region of Brazil, reported that, despite their high phenolic and flavonoid content, none of the ethanol extracts of bee pollen efficiently inhibited microbial growth, either on the Minimum Inhibitory Concentration (MIC) or Minimal Bactericidal Concentration (MBC) tests. The microorganisms studied in that work were B. B. subtilis ATCC 2I,332 
Table 3. Pearson's correlation between phenols, flavonoids, and antioxidant activity of the ethanol extracts of the samples of dehydrated bee pollen: $\mathrm{IC}_{50}$ (mg pollen/mL extract), $\beta$-carotene system (\%), ORAC ( $\mu$ mol eq.Trolox/g pollen) ${ }^{\prime}$.

\begin{tabular}{|c|c|c|c|c|c|}
\hline Correlation & & $\begin{array}{c}\text { Total phenols } \\
\text { (mg GAE/ } \\
\text { g pollen } \\
\end{array}$ & $\begin{array}{l}\text { Total flavonoids } \\
\text { (mg quercetin/ } \\
\text { g pollen) }\end{array}$ & $\begin{array}{c}\mathrm{DPPH} \mathrm{EC}_{50}(\mathrm{mg} \\
\text { pollen/ } \\
\mathrm{mL} \text { extract })\end{array}$ & $\begin{array}{l}\text { ORAC ( } \mu \mathrm{mol} \\
\text { eq.Trolox } \\
\text { /g pollen) }\end{array}$ \\
\hline $\begin{array}{l}\text { Total Flavonoids } \\
\text { (mg quercetin/ } \\
\text { g pollen) }\end{array}$ & $\begin{array}{l}r \\
p\end{array}$ & $\begin{array}{c}0.480 \\
<0.001\end{array}$ & & & \\
\hline $\begin{array}{l}\text { DPPH IC } \mathrm{C}_{50}(\mathrm{mg} \\
\mathrm{pollen} / \\
\mathrm{mL} \text { extract })\end{array}$ & $\begin{array}{l}r \\
P\end{array}$ & $\begin{array}{l}-0.436 \\
<0.001\end{array}$ & $\begin{array}{c}-0.220 \\
0.086\end{array}$ & & \\
\hline $\begin{array}{l}\text { ORAC ( } \mu \mathrm{mol} \\
\text { eq.Trolox } \\
\text { /g pollen) }\end{array}$ & $\begin{array}{l}r \\
p\end{array}$ & $\begin{array}{l}0.568 \\
<0.001\end{array}$ & $\begin{array}{l}0.539 \\
<0.001\end{array}$ & $\begin{array}{l}-0.479 \\
<0.001\end{array}$ & \\
\hline Beta (\%) & $\begin{array}{l}r \\
p\end{array}$ & $\begin{array}{c}0.484 \\
<0.001\end{array}$ & $\begin{array}{l}0.055 \\
0.671\end{array}$ & $\begin{array}{c}-0.419 \\
0.001\end{array}$ & $\begin{array}{c}0.436 \\
<0.001\end{array}$ \\
\hline
\end{tabular}

${ }^{1} \mathrm{~N}=62$; r: Pearson's correlation coefficient; $\mathrm{p}$ : probability associated with the test.

P. aeruginosa ATCC 15,442, Streptococcus mutans Ingbritt 1600, S. aureus ATCC 25,923, Klebsiella pneumoniae, Agrobacterium tumefaciens, Xanthomonas vesicatoria pv.vesicatoria, Xanthomonas axonopodispv. vesicatoria and Pseudomonas syringaepv. tomato), and the methodology used was the agar diffusion test.

Overall, the results obtained by this, and the other mentioned studies suggest that the botanical origin of the samples directly affects their biological action. The achieved results indicate the need for further studies, particularly regarding the isolation and identification of the main active compounds responsible for the antibacterial activity. These may open doors for their future use by the pharmaceutical industry, given the vast number of microorganisms that have become resistant to existing antibacterial drugs.

In the last 60 years, the resistance of human and animal pathogens to antibiotics has been one of the bestdocumented cases of biological evolution and constitutes the main problem faced by Public Health in the world, affecting both developed and developing countries (Davies \& Davies, 2010). This fact is an inevitable consequence of the indiscriminate use of antibiotics in humans and animals. In Europe and North America, $S$. aureus resistant to methicillin (MRSA), Streptococcus pneumoniae not susceptible to penicillin (PNSSP), enterococcus resistant to vancomycin (VRE), and Enterobacteriaceae producers of beta-lactamase of an amplified spectrum (ESBL) have emerged and spread in hospitals and communities (Santos, 2004). Baquero and Blázquez (1997) have commented on the danger of a return to a pre-antibiotic era, especially given the fact that no new class of antibiotics has been discovered in recent years, despite the intense research undertaken by the pharmaceutical industry. In the light of the present scenario, the search for new antimicrobial substances on the base of natural sources, including plants and products such as bee pollen, has assumed great importance in pharmaceutical companies. The best of our knowledge, microorganisms with resistance to the action of bee pollen have not been discovered (Pascoal et al., 20I4), which further highlights its potentiality as a complement to the conventional antimicrobial agents against resistant pathogens.

\section{Correlations}

The study of the botanical origin, involving 62 samples of dehydrated bee pollen, is appropriately discussed in a previous article (Freitas et al., 20I3). Only weak and moderate correlations were observed between the pollen types studied and the parameters (total phenolics, total flavonols, DPPH, ORAC, $\beta$-carotene, and linoleic acid method, and antibacterial activity) evaluated for the dehydrated samples of bee pollen. Moreover, moderate and weak correlations were also observed between the studied parameters (total phenolics, total flavonols, DPPH, ORAC, $\beta$-carotene, and linoleic acid method, and antibacterial activity) (Table 3 ).

\section{Conclusions}

It was demonstrated that bee pollen carries flavonols and phenolic compounds with antioxidant activity. Thereby bee pollen may be useful in the prevention of those diseases in which free radicals are involved. It is, further, notable that bee pollen has promising antimicrobial properties, particularly taking into account the increasing bacterial resistance to the conventional commercial antibiotics. Further study for the isolation of active compounds and in vivo assays are necessary, so that the observations presented in this article may be confirmed.

\section{Disclosure statement}

No potential conflict of interest was reported by the authors.

\section{Funding}

This work was supported by the São Paulo Research Foundation (FAPESP); under Grant \#2009/52163-5 (thesis doctoral project) the Coordination for the Improvement of 
Higher Education Personnel (CAPES); and the National Council for Scientific and Technological Development (CNPq).

\section{ORCID}

Vanilda Aparecida Soares de Arruda (iD http://orcid.org/00000002-7498-87I5

Alexandre Vieria dos Santos (D) http://orcid.org/0000-00028774-8075

Davi Figueiredo Sampaio (iD) http://orcid.org/0000-00024799-|79|

Elias da Silva Araújo (D) http://orcid.org/0000-0002-2507-793 I André Luís de Castro Peixoto (iD http://orcid.org/0000-00032655-2025

Leticia M. Estevinho iD http://orcid.org/0000-0002-9249-1948

Ligia Bicudo de Almeida-Muradian (D) http://orcid.org/0000-

$0001-5322-1358$

\section{References}

Abouda, Z., Zerdani, I., Kalalou, I., Faid, M., \& Ahami, M. T. (20II). The antibacterial activity of Moroccan bee bread and bee-pollen (fresh and dried) against pathogenic bacteria. Research Journal of Microbiology, 6(4), 376-384. https://doi. org/I0.3923/jm.20II.376.384

Ahn, M.-R., Kumazawa, S., Hamasaka, T., Bang, K.-S., \& Nakayama, T. (2004). antioxidant activity and constituents of propolis collected in various areas of Korea. Journal of Agricultural and Food Chemistry, 52(24), 7286-7292. https:// doi.org/10.1021/jf048726s

Almaraz-Abarca, N., Campos, M. G., Delgado-Al, E. A., AvilaReye, J. A., Herrera-Co, J., Gonzalez-V, L. S., Naranjo-Ji, N., Frigerio, C., Tomatas, A. F., Almeida, A. J., Vieira, A., \& Uribe-Soto, J. N. (2008). Pollen flavonoid/phenolic acid composition of four species of cactaceae and its taxonomic significance. American Journal of Agricultural and Biological Sciences, 3(3), 534-543.

Almas, K., Mahmoud, A., \& Dahlan, A. (200I). A comparative study of propolis and saline application on human dentin. A SEM study. Indian Journal of Dental Research: Official Publication of Indian Society for Dental Research, I2(I), 2I-27.

Arruda, V. A. S. D. (2013). Dehydrated bee pollen: physical-chemical composition, microbiological quality, phenolic and flavonoid compounds, antioxidant capacity and botanical origin/ Dehydrtated bee pollen: physicochemical, microbiological quality, phenolic and flavonoids compounds, antioxidant and botanical origin [Thesis]. University of São Paulo.

Arruda, V. A. S. D., Freitas, A. D. S. D., Barth, O. M., Estevinho, L. M., \& Almeida-Muradian, L. B. (20/3). Propriedades biológicas do pólen apícola de coqueiro, coletado na Região Nordeste do Brasil. Magistra, 25, 27-36.

Baquero, F., \& Blázquez, J. (1997). Evolution of antibiotic resistance. Trends in Ecology \& Evolution, 12(12), 482-487. https://doi.org/I0.10I6/S0I69-5347(97)0I223-8

Basim, E., Basim, H., \& Özcan, M. (2006). Antibacterial activities of Turkish pollen and propolis extracts against plant bacterial pathogens. Journal of Food Engineering, 77(4), 992-996. https://doi.org//0.1016/j.jfoodeng.2005.08.027

Brenna, O. V., \& Pagliarini, E. (200I). Multivariate analysis of antioxidant power and polyphenolic composition in red wines. Journal of Agricultural and Food Chemistry, 49(10), 484 I-4844. https://doi.org/I0.102 I/jf0 I 04376

Campos, M. G., Almaraz-Abarca, N., Matos, M. P., Gomes, N. M., Arruda, V. A. S., Barth, O. M., Freitas, A. S., \& Almeida-Muradian, L. B. (20I5). Zea mays L. Pollen: An approach to its quality control. Journal of Agricultural Science and Technology B, 5(8), 5|3-522. https://doi.org//0.17265/ 2161-6264/2015.08.001

Campos, M. G., Webby, R. F., Markham, K. R., Mitchell, K. A., \& da Cunha, A. P. (2003). Age-induced diminution of free radical scavenging capacity in bee pollens and the contribution of constituent flavonoids. Journal of Agricultural and Food Chemistry, 5I(3), 742-745. https://doi.org/I0.102I/jf0206466

Campos, M. G., Webby, R. F., Mitchell, K. A., Coleta, M., Markham, K. R., \& Cunha, A. P. (2000). Free-radical scavenging properties of bee pollens - the non-involvement of flavonoids? In International Conference of Polyphenols (PP. II-I5). Poster.

Carpes, S. T., Begnini, R., Alencar, S. M. d., \& Masson, M. L. (2007). Study of preparations of bee pollen extracts, antioxidant and antibacterial activity. Ciência e Agrotecnologia, $3 /(6), \quad$ I8I8-1825. https://doi.org/I0.1590/SI4/370542007000600032

Carpes, S. T., Prado, A., Moreno, I. A. M., Mourão, G. B., Alencar, S. M. de, \& Masson, M. L. (2008). Avaliação do potencial antioxidante do pólen apícola produzido na região sul do Brasil. Química Nova, 3/(7), 1660-1664. https://doi. org/10.1590/S0100-404220080007000II

Carpes, S. T., Ribeiro, I. S., Rosalen, P. L., de Alencar, S. M., \& Masson, M. L. (2009). Caracterização do Potencial Antimicrobiano Dos Extratos De Pólen Apícola Da Região Sul Do Brasil. Alimentos E Nutrição Araraquara, 20(2), 27I-277.

Davies, J., \& Davies, D. (2010). Origins and evolution of antibiotic resistance. Microbiology and Molecular Biology Reviews: MMBR, 74(3), 4/7-433. https://doi.org//0.1/28/MMBR. 00016-10

de Arruda, V. A. S., Pereira, A. A. S., de Freitas, A. S., Barth, O. M., \& de Almeida-Muradian, L. B. (2013a). Dried bee pollen: B complex vitamins, physicochemical and botanical composition. Journal of Food Composition and Analysis, 29(2), 100-105. https://doi.org/I0.1016/j.jfca.2012.11.004

de Arruda, V. A. S., Santos Pereira, A. A., Estevinho, L. M., \& de Almeida-Muradian, L. B. (20I3b). Presence and stability of $B$ complex vitamins in bee pollen using different storage conditions. Food and Chemical Toxicology: An International Journal Published for the British Industrial Biological Research Association, 5I, 143-148. https://doi.org//0.1016/j.fct.2012. 09.019

Di Paola-Naranjo, R. D., Sánchez-Sánchez, J., GonzálezParamás, A. M., \& Rivas-Gonzalo, J. C. (2004). Liquid chromatographic-mass spectrometric analysis of anthocyanin composition of dark blue bee pollen from Echium plantagineum. Journal of Chromatography. A, 1054(I-2), 205-210. https://doi.org/I0.1016/j.chroma.2004.05.023

Duarte, M. C. T., Leme, E. E., Delarmelina, C., Soares, A. A., Figueira, G. M., \& Sartoratto, A. (2007). Activity of essentia oils from Brazilian medicinal plants on Escherichia coli. Journal of Ethnopharmacology, III(2), 197-20I. https://doi. org/10.1016/j.jep.2006.1 I.034

Estevinho, L., Pereira, A. P., Moreira, L., Dias, L. G., \& Pereira, E. (2008). Antioxidant and antimicrobial effects of phenolic compounds extracts of Northeast Portugal honey. Food and Chemical Toxicology : An International Journal Published for the British Industrial Biological Research Association, 46(12), 3774-3779. https://doi.org/I0.1016/j.fct.2008.09.062

Fatrcová-Šramková, K., Nôžková, J., Kačániová, M., Máriássyová, M., Rovná, K., \& Stričík, M. (20I3) Antioxidant and antimicrobial properties of monofloral bee pollen. Journal of Environmental Science and Health. Part. B, Pesticides, Food Contaminants, and Agricultural Wastes, 48(2), 133-138. https://doi.org//0.1080/0360/234.20/3.727664

Freitas, A. S., Arruda, V. A. S., Muradian, L. B. A., Barth, O. M. (2013). The botanical profiles of dried bee pollen loads 
collected by Apis mellifera (Linnaeus) in Brazil. Sociobiology, 60, 56-64. https://doi.org//0.13102/sociobiology.v60il

Gabriele, M., Parri, E., Felicioli, A., Sagona, S., Pozzo, L., Biondi, C., Domenici, V., \& Pucci, L. (2015, February). Phytochemical composition and antioxidant activity of Tuscan bee-pollen of different botanical origins. Italian Journal of Food Science, 27, 248-259.

Gebara, E. C. E., Lima, L. A., \& Mayer, M. P. A. (2002). Propolis antimicrobial activity against periodontopathic bacteria. Brazilian Journal of Microbiology, 33(4), 365-369. https://doi.org/I0.1590/SI5I7-838220020004000I8

Gondim, B. (20lI). Atividade Antimicrobiana de Produtos Naturais Frente a Bactérias Formadoras do Biofilme Dentário. Pesquisa Brasileira em Odontopediatria e Clínica Integrada, II(I), 123-I27. https://doi.org//0.4034/PBOCI. 2011.111 .19

Graikou, K., Kapeta, S., Aligiannis, N., Sotiroudis, G., Chondrogianni, N., Gonos, E., \& Chinou, I. (20II). Chemical analysis of Greek pollen - Antioxidant, antimicrobial and proteasome activation properties. Chemistry Central Journal, 5(I), 33. https://doi.org//0.1 I86/1752-153X-5-33

Kacaniová, M., Vukovic, N., Chlebo, R., Hascik, P., Rovná, K., Cubon, J., Dzugan, M., \& Pasternakiewicz, A. (20I2). The antimicrobial activity of honey, bee pollen loads and beeswax from Slovakia. Archives of Biological Sciences, 64(3), 927-934.

Knazovická, V., Melich, M., Kacániová, M., \& Fikselová, M. (2009). Antimicrobial activity of selected bee products. Acta Fytotechnica et Zootechnica - Mimoriadne Cislo, 12, 280-285.

Liberato, M. C. T. C., Morais, S. M., Salustiano, G. L., Nojosa, A. C. B., \& Nojosa, A. K. B. (2009). Determinação de fenóis totais e flavonoides em amostras de pólen apícola de Appis mellifera I. do Ceará. In R. Noll (Ed.). Proceedings of the 49th Congresso Brasileiro de Química.

Lobo, V., Patil, A., Phatak, A., \& Chandra, N. (2010). Free radicals, antioxidants and functional foods: Impact on human health. Pharmacognosy Reviews, 4(8), I18-126. https://doi. org// 0.4103/0973-7847.70902

Mărgăoan, R., Mărghitaş, L. A., Dezmirean, D. S., Dulf, F. V., Bunea, A., Socaci, S. A., \& Bobiş, O. (20I4). Predominant and Secondary Pollen Botanical Origins Influence the Carotenoid and Fatty Acid Profile in Fresh HoneybeeCollected Pollen. J Agric Food Chem, 62(27), 6306-6316. https://doi.org/I0.1021/jf50203/8

Meneses, J. D. D. S., Maciel, L. F., Miranda, M. S., \& Druzian, J. I. (2010). Compostos bioativos e potencial antioxidante do pólen apícola produzido por abelhas africanizadas (Apis mellifera L.). Revista Instituto Adolfo Lutz, 69(2), 233-242. http://revistas.bvs-vet.org.br/rialutz/article/view/6367

Morais, M., Moreira, L., Feás, X., \& Estevinho, L. M. (20II). Honeybee-collected pollen from five Portuguese Natural Parks: Palynological origin, phenolic content, antioxidant properties and antimicrobial activity. Food and Chemical Toxicology: An International Journal Published for the British Industrial Biological Research Association, 49(5), 1096-II0I. https://doi.org/l0.1016/j.fct.201 I.01.020

Mundargi, R. C., Potroz, M. G., Park, S., Shirahama, H., Lee, J. H., Seo, J., \& Cho, N.-J. (20l6). Natural sunflower pollen as a drug delivery vehicle. Small (Weinheim an Der Bergstrasse, Germany)), I2(9), II67-II73. https://doi.org/I0. I002/smll.201500860

Neves, L. C., Alencar, S. M. d., \& Carpes, S. T. (2009). Determinação da atividade antioxidante e do teor de compostos fenólicos e flavonoides totais em amostras de pólen apícola de Apis mellifera. Brazilian Journal of Food Technology, VII BMCFB, 7, 107-II0.

Nogueira, M. A., Diaz, M. G., Tagami, P. M., \& Lorscheide, J. (2007). Atividade microbiana de óleos essenciais e extratos de própolis sobre bactérias cariogênicas. Revista de Ciencias Farmaceuticas Basica E Aplicada, 28(I), 93-97.

Oršolić, N., Knežević, A. H., Šver, L., Terzić, S., \& Bašić, I. (2004). Immunomodulatory and antimetastatic action of propolis and related polyphenolic compounds. Journal of Ethnopharmacology, 94(2-3), 307-3/5. https://doi.org//0. I016/j.jep.2004.06.006

Ou, B., Hampsch-Woodill, M., \& Prior, R. L. (200I). Development and validation of an improved oxygen radica absorbance capacity assay using fluorescein as the fluorescent probe. Journal of Agricultural and Food Chemistry, 49(10), 4619-4626. https://doi.org//0.102I/jf0 I0586o

Ozan, F., Sümer, Z., Polat, Z. A., Er, K., Ozan, U., \& Deger, O. (2007, October). Effect of mouthrinse containing propolis on oral microorganisms and human gingival fibroblasts. European Journal of Dentistry, I (4), I95-20I.

Özcan, M., Ünver, A., Ceylan, D. A., \& Yetisir, R. (2004). Inhibitory effect of pollen and propolis extracts. Nahrung/ Food, 48(3), 188-194. https://doi.org/10.1002/food.200300296

Özkalp, B., \& Özcan, M. M. (2010). Antibacterial activity of pollen and propolis extracts. Journal of Food, Agriculture and Environment, 8(2), 17-19.

Pascoal, A., Rodrigues, S., Teixeira, A., Feás, X., \& Estevinho, L. M. (20|4). Biological activities of commercial bee pollens: Antimicrobial, antimutagenic, antioxidant and anti-inflammatory. Food and Chemical Toxicology: An International Journal Published for the British Industrial Biological Research Association, 63, 233-239. https://doi.org/I0.1016/j.fct.2013.1 I.010

Pereira, J. A., Oliveira, I., Sousa, A., Valentão, P., Andrade, P. B., Ferreira, I. C. F. R., Ferreres, F., Bento, A., Seabra, R., \& Estevinho, L. (2007). Walnut (Juglans regia L.) leaves: Phenolic compounds, antibacterial activity and antioxidant potential of different cultivars. Food and Chemical Toxicology: An International Journal Published for the British Industrial Biological Research Association, 45(II), 2287-2295. https:// doi.org/I0.1016/j.fct.2007.06.004

Sakanaka, S., \& Ishihara, Y. (2008). Comparison of antioxidant properties of persimmon vinegar and some other commercial vinegars in radical-scavenging assays and on lipid oxidation in tuna homogenates. Food Chemistry, 107(2), 739-744. https://doi.org// 0.1016/j.foodchem.2007.08.080

Santos, N. d Q. (2004). A resistência bacteriana no contexto da infecção hospitalar. Texto \& Contexto - Enfermagem, 13(spe), 64-70. https://doi.org// 0.1590/S0 I04-07072004000500007

Scazzocchio, F., D'Auria, F. D., Alessandrini, D., \& Pantanella, F. (2006). Multifactorial aspects of antimicrobial activity of propolis. Microbiological Research, I6I(4), 327-333. https:// doi.org/10.1016/j.micres.2005.12.003

Uzel, A., Sorkun, K., Onçă̆, O., Cogŭlu, D., Gençay, O., \& Salih, B. (2005). Chemical compositions and antimicrobial activities of four different Anatolian propolis samples. Microbiological Research, 160(2), 189-195. https://doi.org//0. 1016/j.micres.2005.01.002

Vecchia, P. D., \& Carpes, S. T. (2010). Avaliação da atividade antioxidante dos extratos de pólen apícola (determinação de compostos fenólicos e flavonóides totais), 30.

Wiermann, R., \& Vieth, K. (1983). Outer pollen wall, an important accumulation site for flavonoids. Protoplasma, I/8(3), 230-233. https://doi.org//0.1007/BF0|28I807

Yang, K., Wu, D., Ye, X., Liu, D., Chen, J., \& Sun, P. (2013). characterization of chemical composition of bee pollen in China. Journal of Agricultural and Food Chemistry, 6I(3), 708-7/8. https://doi.org//0.1021/jf304056b

Yıldırım, A., Mavi, A., \& Kara, A. A. (200I). Determination of antioxidant and antimicrobial activities of Rumex crispus $L$. extracts. Journal of Agricultural and Food Chemistry, 49(8), 4083-4089. https://doi.org//0.1021/jf0 03572 